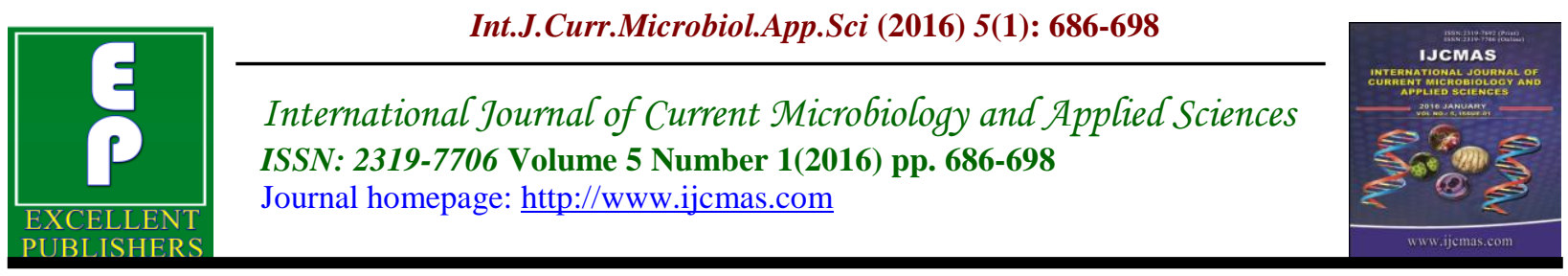

Original Research Article

http://dx.doi.org/10.20546/ijcmas.2016.501.069

\title{
Detection and Genotyping of Human Papilloma Virus (HPV) As a Cause of Recurrent Early Pregnancy Loss
}

\author{
Aya A. Hammad ${ }^{1}$, Neveen A. Ashaat ${ }^{1}$, Samah F. Darwish ${ }^{2}$, I.I. Moustafa ${ }^{3}$ and A.S. Amin ${ }^{2}$ \\ ${ }^{1}$ Faculty of Women for Arts, Science and Education, Ain Shams University, Egypt \\ ${ }^{2}$ Biotechnology Research Unit, Animal Reproduction Research, Giza, Egypt \\ ${ }^{3}$ Department of Obstetrics \& Gynecology, Faculty of Medicine, Ain Shams University, Egypt
}

*Corresponding author

\begin{abstract}
A B S T R A C T
Keywords

Human

papillomavirus

(HPV),

Molecular

diagnostics,

Recurrent early

pregnancy loss,

Nested PCR

Article Info

Accepted:

25 December 2015

Available Online:

10 January 2016

Human papillomavirus (HPV) is the most common sexually transmitted infection (STI). HPV is so common that nearly all sexually active men and women get it at some point in their lives. The objective of the this study is to assess whether or not there is an association between HPV and unexplained recurrent early pregnancy loss (REPL). Genomic DNA was extracted from the collected paired placenta and urine samples and was submitted to PCR methods with the primers MY09/11 and nPCR with the pair of primers MY09/MY11 and GP5+/6+. HPV-positive samples were typed by multiplex PCR for four high-risk HPV (HR-HPV) (HPV-16, 18, 31 and 51). Agreement between paired sample results was evaluated. The results indicated that, HPV infection was found as $16.6 \%$ and $26.7 \%$ in placental samples, $6.6 \%$ and $36.7 \%$ in urine samples by using PCR and nPCR or real-time PCR respectively. HPV-16 was the predominance HPV type in both sample (10\%) followed by HPV-31(6.6\%) in both samples and HPV- types 51 and $18(3.3 \%)$ in both samples. There was $3.3 \%$ co infection (infection by more than one type of HPV) in placenta and urine samples by types 16 and 51. There was poor agreement of placenta and urine samples results in generic and a moderate agreement for typespecific detection of HPV. The results also showed a significantly difference between number of miscarriage in HPV positive $(3.38 \pm 0.744)$ and HPV negative $(2.95 \pm 0.385)$ placenta samples. In conclusion HPV infection of trophoblast may cause placental dysfunction and is associated with adverse pregnancy outcomes, including recurrent early pregnancy loss.
\end{abstract}

\section{Introduction}

Human papillomavirus (HPV) is one of the commonest sexually transmitted infections. Over $50 \%$ (Up to $80 \%$ ) of sexually active women are infected at some point in their lives and 10-20\% develops persistent infection (Einstein et al., 2009). The study of HPVs has been driven not by these widespread in apparent infections, but by the severity to which some HPV-associated diseases can progress. Most significant of 
these is cervical cancer, which can result from persistent infection with a group of "high-risk" HPVs (Goon et al., 2008 and Doorbar et al., 2012).

There was number of investigators reported that HPV infected trophoblast cells within the placenta from early pregnancy losses and it was threefold more prevalent in spontaneous abortions than in elective terminations of pregnancy (Hermonat et al., 1997; Malhomme et al., 1997 and Hermonat et al., 1998) . Thus, the disruption of the trophoblastic layer by HPV could likely result in abnormal plantation or expulsion of the gestation (Clark et al., 1993).

Recurrent pregnancy loss (RPL) was defined as the occurrence of two or more failed pregnancies', according to the American Society for Reproductive Medicine, diagnosed either by ultrasound examination or by histopathology (Allison and Schust 2009; Donckers et al., 2012 and Ibrahim et al., 2014).

There are currently several techniques for the molecular diagnosis of HPV, ranging from a conventional Polymerase Chain Reaction (PCR) methods complex, such as real-time PCR, hybrid capture (HC) and microarray (Gravitt et al., 2000 and Choi et al., 2005). The PCR technique is still considered the "gold standard" for HPV diagnosis (Trofatter, 1997).

For the genotyping of HPV, the target products amplified by PCR are subjected to sequence analysis (Asato et al., 2004), restriction fragment length polymorphism analysis (RFLP) analysis (Yoshikawa et al., 1991; Bernard et al., 1994 and Sasagawa et al., 2000), and hybridization with typespecific probes (Kleter et al., 1999; Han et al., 2006 and Jiang et al., 2006), Reverse line blot assays have also been developed and validated (Gravitt et al., 1998).

The main aim of this study was to investigate the role that could be played by HPV as a causative agent of RPL. This was based on detection of HPV in both placenta and urine samples collected from women suffering from RPL using different PCR assays including conventional, nested and qPCR assays. Additionally, comparative evaluation of the adopted PCR assays was done.

\section{Materials and Methods}

\section{Patients and Specimen Collection}

This is a case control study. Paired samples including both urine and placenta were collected. Case group included samples from women with recurrent miscarriage attending outpatient clinics of Ain Shams University Maternity Hospital, Cairo, Egypt between 24 and 38 years old $(32.67 \pm 3.209)$ and the gestational age was between 8 and 14 weeks $(10.93 \pm 1.982)$. Patients with chronic or hereditary diseases were excluded. Control group included samples collected from women presented with first missed miscarriage, with no history of recurrent early pregnancy loss and had at least one previous uneventful pregnancy with no previous obstetric history of adverse pregnancy outcomes.

All the women enrolled in the study were informed about the research objective. This study was approved by the Ethical Board of Ain Shams University, Faculty of Medicine. Each woman's placenta and urine samples were taken on the same day; the urine specimen was self-collected on EDTA according to Antje et al., 1999 kept at-80 before DNA extraction. 


\section{DNA Extraction from Placental and Urine Samples}

DNA was extracted from placenta tissue and urine samples by chelex-100using a modified protocol from that of Walsh et al. (1991).

\section{HPV Detection by PCR}

All samples were subjected for three different PCR assays to detect HPV for comparative evaluation. A set of primer targeting the aminolevulinate deltasynthase lgene (Gen Bank accession no. NM 000688), table 1, was included in each PCR reaction as an internal control for DNA adequacy to avoid false-negative results in different PCR assays according to Morie et al. (2008).

\section{Gp5+/6+conventional PCR Assay}

HPV was detected by PCR using hot start master mix (QIAGEN),-and the Gp5+/6+ general primers (Table 1) described by weimin et al., 1997 . The PCR reaction was performed in a final volume of $25 \mu \mathrm{L}$ containing $12.5 \mu \mathrm{l}$ PCR Hot Start Master Mix, 25 pmol from each $\mathrm{Gp} 5+/ 6+$ primers, $0.5 \mu \mathrm{l}$ of DNA and $6.5 \mu \mathrm{l}$ water. The reaction condition was as follows: 40 cycles of denaturation $1 \mathrm{~min}$ at $95^{\circ} \mathrm{C}$, annealing 1 min at $40^{\circ} \mathrm{C}$, and extension $2 \mathrm{~min}$ at $72^{\circ} \mathrm{C}$ followed by final extension cycle of $72^{\circ} \mathrm{C}$ for 10 min, according to De Roda husman et al., 1995 .

\section{Nested PCR Assay}

In this assay, HPV detection was carried out using two rounds of PCR: the first round utilize MY09/11 primers (Gravitt et al., 2000) (Table 1), while the second round used GP5+/6+ primers, which amplify the $150 \mathrm{pb}$ fragment. All reactions were performed in a final volume of $25 \mu \mathrm{L}$, containing hot start PCR master mix (QIAGEN). The temperature profile for the first round and for second round were performed according to Strauss et al. (1999). All PCR products were visualized on a $2.0 \%$ agarose gel.

\section{Real Time PCR Assay}

Real-time amplification of the HPV DNA was performed in a total volume of $25 \mu 1$ using $\mathrm{Gp} 5+/ 6+$ primer pair. All reactions were performed in a final volume of $25 \mu \mathrm{L}$, containing $1 \times$ SYBR Green PCR master mix (QIAGEN), as described previously (De Araujo et al., 2009). The thermal cycle protocol was performed on one step RealTime PCR Detection System (Corbett Research, Australia). The PCR was then followed by a melt analysis program. Melt curve analysis was performed by heating the PCR products from $60^{\circ} \mathrm{C}$ to $95^{\circ} \mathrm{C}$. The fluorescence data was collected at the end of each extension step and continuously during the melt curve program by SYBR green channel. Each run included both positive control and negative (no template) control. Samples considered positive when its fluorescence exceed the threshold and its melt curve analysis was specific.

\section{Genotyping of Human Papilloma Virus}

HPV in positive samples were genotyped using multiplex PCR assay targeting 4 genotypes of high risk HPV using 5 sets of genotype-specific primers that could amplify specific regions of 4 types of high risk- HPV DNA $(16,18,31$, and 51). One additional primer set was used for HPV type 16 to ensure identification of its 2 serotypes (Table 1). PCR was performed with a multiplex PCR kit (Qiagen) according to Morie et al. (2008). 


\section{Statistical Analysis}

Data are processed with SPSS (version 16.0). $T$ test was used to detect difference between negative and positive HPV samples on level of patient data. Kappa agreement test was used to compare between different tests adopted for detection of HPV.

\section{Results and Discussion}

All samples including both placenta and urine samples were subjected for HPV detection by GP5+/6+ conventional PCR assay, nested PCR assay and real time PCR assay. Fig 1 and 2 showed the PCR products of both the GP5+/6+ conventional PCR assay and nested PCR assay in both placenta and urine samples, respectively. Fig 3 and 4 showed the amplification and melting curves of represented of HPV positive and negative samples using real time PCR assay in both placenta and urine samples, respectively.

HPV was detected in 5 placenta samples out of $30(16.6 \%)$ by GP5+/6+ conventional PCR assay versus $8(26.7 \%)$ found positive by both nested and real time PCR assays. On the other hand, $2(6.6 \%)$ urine samples were HPV positive by GP5+/6+ conventional PCR assay versus $11(36.7 \%)$ found positive by both nested and real time PCR assays. Comparative evaluation between the three tests adopted for detection of HPV detection revealed a substantial agreement (Kappa agreement $=62.3 \%$ ) between GP5+/6+ conventional PCR and the nested or real time PCR assay in placenta samples, while a fair agreement ( kappa agreement = $22.6 \%$ ) was detected between the same assays in urine samples . Complete agreement (kappa agreement $=100 \%)$ was detected between the nested and the real time PCR assays as they both detected the same number of positive HPV samples.
Additionally, a multiplex PCR assay specific for genotypes 16, 18, 31, 51 of HPV were used to detect the specific genotype in all the HPV positive samples (Fig. 5). Table 2 showed the number of different genotypes detected in different types of samples. Comparison between HPV positive and negative samples on the level of patient data was statistically evaluated. Significant difference was found between number of miscarriage in HPV positive $(3.38 \pm 0.744)$ and HPV negative $(2.95 \pm 0.385)$ placenta samples. Also, significant difference was found in gestational age between HPV positive $(12.09 \pm 1.7)$ and HPV negative (10.26 \pm 1.851$)$ urine samples (Table 3).

HPVs are well known to be pathogenic viruses and are the largest risk factor in the development of cervical cancer (Melbye and Frisch, 1998). Trophoblasts may represent a new host cell type; these data also support the hypothesis that HPV infection of trophoblasts may be linked to some spontaneous abortions (Noventa et al., 2014). The search for factors that may be implicated in spontaneous abortion has led to the examination of numerous factors, including maternal age, number of miscarriage and gestational age. There are several comparative studies of different methods for HPV-DNA detection. DNA detection in urine implies a number of challenges: it is a diluted sample and contains both known, such as urea and nitrites, and unknown polymerase chain reaction (PCR) inhibitors (Khan et al., 1991). Antje et al. (1999) showed that human DNA containing $40 \mathrm{mM}$ EDTA stored at room temperature for 8 days was less degraded than the DNA in urine samples without EDTA frozen at $-20^{\circ} \mathrm{C}$. EDTA , known to be an effective nuclease inhibitor, is a chelating agent of bi-valent cations cofactors of DNA nucleases (Baker, 2009). 
Table.1 Primers used in Different PCR Assays

\begin{tabular}{|c|c|c|c|}
\hline PCR assay & Primer Name & Primer sequence (5'-3') & Product size \\
\hline $\begin{array}{l}\text { Gp5+/6+ } \\
\text { set }\end{array}$ & $\begin{array}{l}\text { Gp5+/6+ F } \\
\text { Gp5+/6+ R }\end{array}$ & $\begin{array}{l}\text { TTT GTT ACT GTG GTA GAT ACT AC } \\
\text { GAA AAA TAA ACT GTA AAT CATATTC } \\
\text { (Weimin } \boldsymbol{e} \text { t al., 1997) }\end{array}$ & $150 \mathrm{bp}$ \\
\hline \multirow[t]{7}{*}{$\begin{array}{l}\text { MY09/11 } \\
\text { set }\end{array}$} & $\begin{array}{l}\text { MY09/11 F } \\
\text { MY9/11 R }\end{array}$ & $\begin{array}{l}\text { CGT CCM ARR GGA WAC TGA TC } \\
\text { GCM CAG GGW CAT AAY AAT GG } \\
\text { (Gravitt } \boldsymbol{e} \text { t al., 2000) }\end{array}$ & $450 \mathrm{bp}$ \\
\hline & $\begin{array}{l}\text { PPx16L/F } \\
\text { PPx16L/R }\end{array}$ & $\begin{array}{l}\text { CGC ACA AAA CGT GCTCGGCT ACC } \\
\text { TGG GAG GCC TTG TTCCCAATG GA } \\
\text { (Morie et al., 2008) }\end{array}$ & $217 \mathrm{bp}$ \\
\hline & $\begin{array}{l}\text { PPx16U/F } \\
\text { PPx16U/R }\end{array}$ & $\begin{array}{l}\text { TCC TGC AGG TAC CAA TGGGGA AGA } \\
\text { GG } \\
\text { TGC CAT ACC CGC TGT CTTCGC TTT } \\
\text { (Morie et al., 2008) }\end{array}$ & $397 \mathrm{bp}$ \\
\hline & $\begin{array}{l}P P \times 18 / F \\
P P \times 18 / R\end{array}$ & $\begin{array}{l}\text { AAC AGT CCA TTA GGG GAG CGG CTG } \\
\text { GA } \\
\text { TGC CGC CAT GTT CGC CATTTG } \\
\text { (Morie et al., 2008) }\end{array}$ & $187 \mathrm{bp}$ \\
\hline & $\begin{array}{l}\mathrm{PP} \times 31 / \mathrm{F} \\
\mathrm{PP} \times 31 / \mathrm{R}\end{array}$ & $\begin{array}{l}\text { GCG GTC CAA ACG CTC TACAAA ACG } \\
\text { CAC T } \\
\text { GCA GGG GCA CCA ACA TCA ACA ATT } \\
\text { CCA } \\
\text { (Morie et al., 2008) }\end{array}$ & $360 \mathrm{bp}$ \\
\hline & $\begin{array}{l}\mathrm{PP} \times 51 / \mathrm{F} \\
\mathrm{PP} \times 51 / \mathrm{R}\end{array}$ & $\begin{array}{l}\text { CAA CTA GCA ACG GCG ATG GAC TG } \\
\text { CTG CTT CGC GGG CTG ACT AGA A } \\
\text { (Morie et al., 2008) }\end{array}$ & 299 bp \\
\hline & $\begin{array}{l}\text { IC/F } \\
\text { IC/R }\end{array}$ & $\begin{array}{l}\text { TTA TCC CGA GTC CCC CAGGCC TTT CT } \\
\text { TGG CTT GGC CCC AAC TTCCAT CA } \\
\text { (Morie et al., 2008) }\end{array}$ & 99 bp \\
\hline
\end{tabular}

The degenerate base code is as follows: $\mathrm{M}=\mathrm{A}$ or $\mathrm{C}, \mathrm{W}=\mathrm{A}$ or $\mathrm{T}, \mathrm{Y}=\mathrm{C}$ or $\mathrm{T}$, and $\mathrm{R}=\mathrm{A}$ or $\mathrm{G}$ ). F: forward primer; $\mathrm{R}$ : reverse primer; IC: internal control

Table.2 Different HPV Genotypes Detected in HPV Positive Placenta and Urine Samples

\begin{tabular}{|c|c|c|}
\hline HPV Genotypes & Placenta No.=8 & Urine No.=11 \\
\hline HPV-16 & $3(10 \%)$ & $3(10 \%)$ \\
\hline HPV-18 & $1(3.3 \%)$ & $1(3.3 \%)$ \\
\hline HPV-31 & $2(6.6 \%)$ & $2(6.6 \%)$ \\
\hline HPV-51 & $1(3.3 \%)$ & $1(3.3 \%)$ \\
\hline HPV-16+51 & $1(3.3 \%)$ & $1(3.3 \%)$ \\
\hline Untyped & 0 & $3(10 \%)$ \\
\hline
\end{tabular}


Table.3 Comparison Between HPV Positive and Negative Samples on the Level of Patient Number of Miscarriage, Patient Age (Year) and Gestational Age(week)

\begin{tabular}{|c|c|c|c|c|}
\hline \multirow{2}{*}{ Patient data } & \multicolumn{2}{|c|}{ Placenta samples } & \multicolumn{2}{c|}{ Urine samples } \\
\cline { 2 - 5 } & $\begin{array}{c}+ \text { ve HPV } \\
\text { No. }=8\end{array}$ & $\begin{array}{c}- \text { ve HPV } \\
\text { No. }=22\end{array}$ & $\begin{array}{c}+ \text { ve HPV } \\
\text { No. } 11\end{array}$ & $\begin{array}{c}\text {-ve HPV } \\
\text { No. }=19\end{array}$ \\
\hline No.of Miscarriage Mean \pm SD & $3.38 \pm 0.744^{*}$ & $2.95 \pm 0.385$ & $3.09 \pm 0.302$ & $3.05 \pm 0.621$ \\
\hline Age Mean \pm SD & $33.9 \pm 1.356$ & $32.23 \pm 3.59$ & $33.82 \pm 1.401$ & $32 \pm 3.771$ \\
\hline Gestational Age Mean \pm SD & $11.75 \pm 1.982$ & $10.64 \pm 1.94$ & $12.09 \pm 1.7 *$ & $10.26 \pm 1.851$ \\
\hline
\end{tabular}

* $=\mathrm{P}<0.05 \quad$ Significant

Fig.1 Agarose Gel Electrophoresis of PCR Products of Placenta and Urine Samples obtained by amplification using Gp5+/6+ Conventional PCR (a) Representatives of Placenta Samples; M: 100 bp molecular DNA marker ; PC: Positive Control; lanes 3, 6, 7, 10 and 11: positive samples. Lanes 1, 2, 5, 6, 9, 10 and 13-23: negative samples. NC: negative control (b) Representatives of urine samples; lane M: 100 bp molecular DNA marker; PC: positive control, lanes 3 and 6: positive samples, Lanes: 1,2,4,5 and 7-23: negative samples. NC: negative control

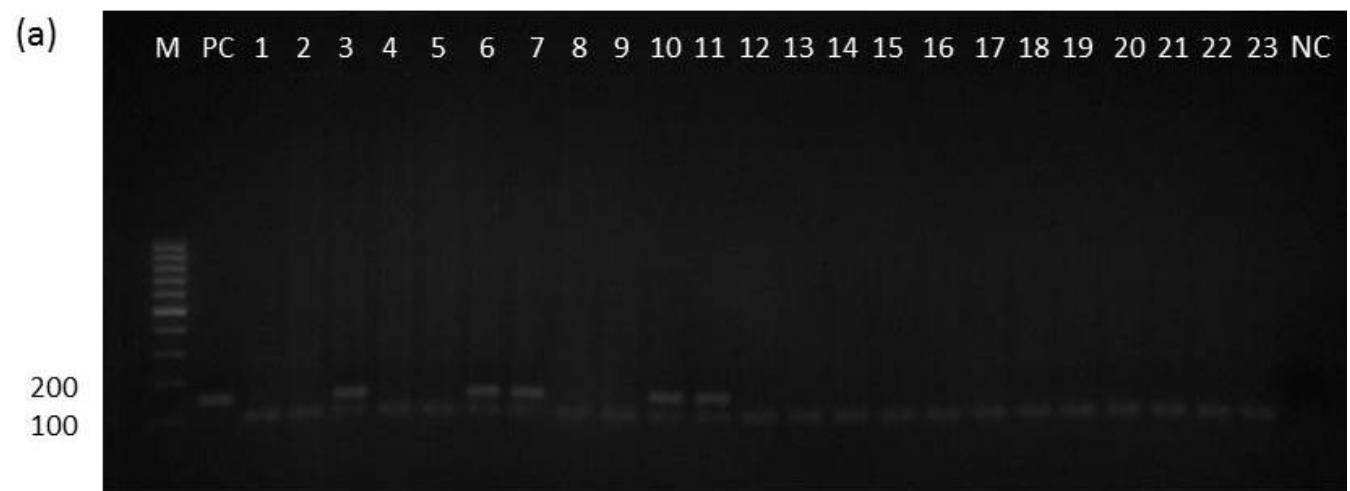

(b)

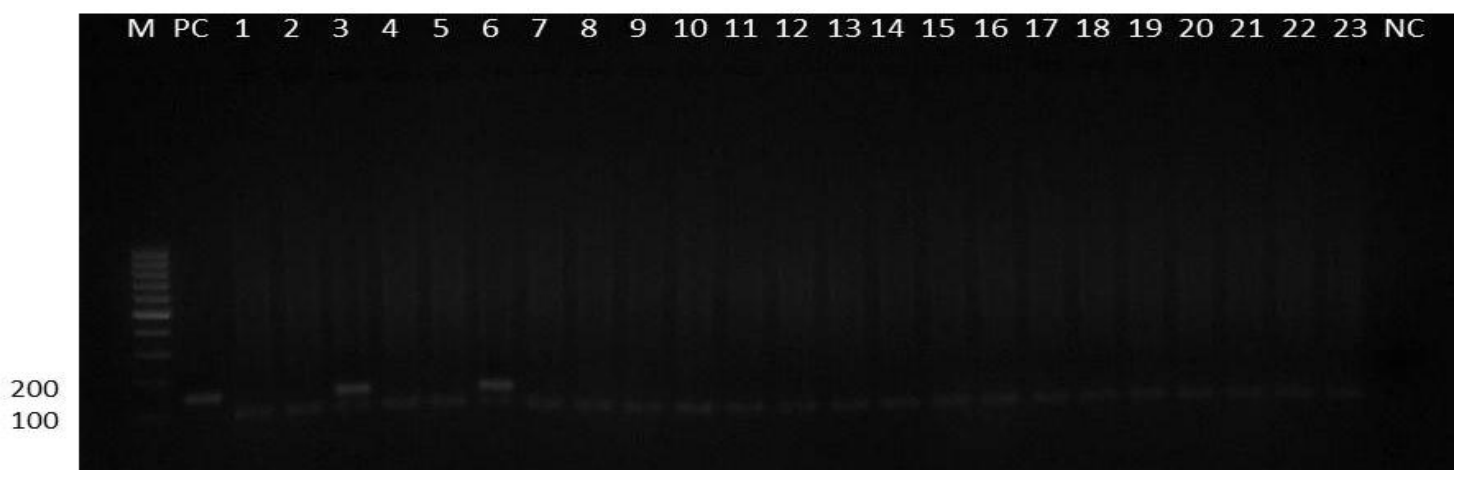


Fig.2 Agarose gel electrophoresis of PCR products of placenta and urine samples obtained by amplification using nested PCR (a) Representatives of placenta samples; M: 100 bp molecular DNA marker; PC: positive control, lanes 3, 6, 7, 10,11,12,17 and 21: positive samples. Lanes $1,2,4,5,8,9,13,14,15,16,18-20,22$ and 23 : negative samples. NC: negative control (b) Representatives of urine samples; lane M: 100 bp molecular DNA marker; PC: positive control. Lanes 3,4,6,9.12,14,15,17,19,21 and 23: positive samples. Lanes: 1,2,5,7,8,10,11,13,16,18,20 and 22 : negative samples. NC: negative control

(a)

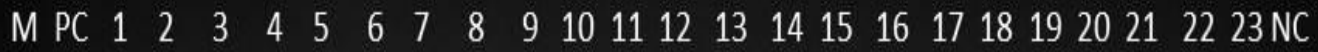

200

100

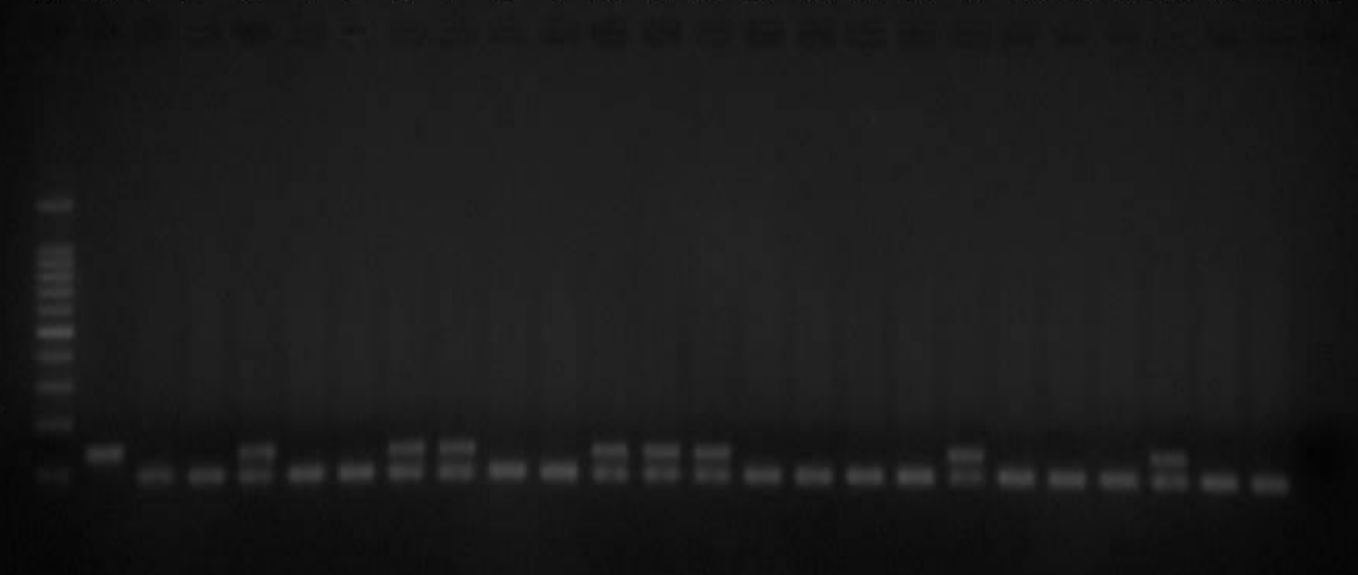

(b)

M PC $\begin{array}{llllllllllllllllllllllll}2 & 2 & 3 & 4 & 5 & 6 & 7 & 8 & 9 & 10 & 11 & 12 & 13 & 14 & 15 & 16 & 17 & 18 & 19 & 20 & 21 & 22 & 23 & \text { NC }\end{array}$

200

100 
Fig.3 Amplification plot and melting curve for HPV detection by Gp5+/6+ SYBR Green Q-RT PCR in placenta samples. (a) Amplification plot for detection of HPV in placenta samples using real time PCR assay: Relative fluorescence units are plotted against cycle number $(\mathrm{Ct})$. (b) Melting curve of HPV positive and negative samples. The $\mathrm{x}$-axis indicates the melting temperatures while the y-axis indicates the fluorescence intensity. : $(\theta)$ HPV positive samples, Tm73.95 C ;(\#) HPV negative samples
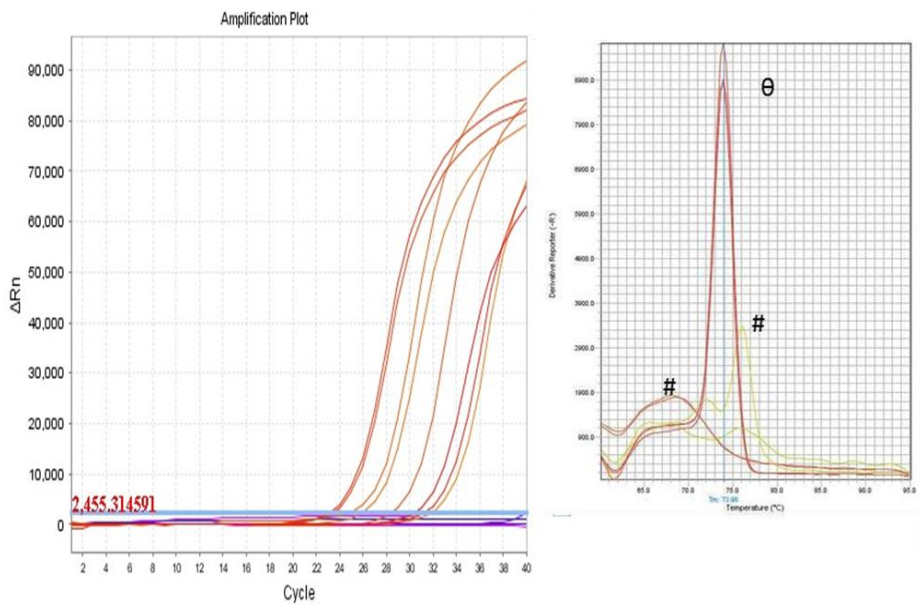

Fig.4 Amplification plot and melting curve for HPV detection by Gp5+/6+ SYBR Green Q-RT PCR in urine samples. (a) Amplification plot for detection of HPV in placenta samples using real time PCR assay: Relative fluorescence units are plotted against cycle number $(\mathrm{Ct})$. (b) Melting curve of HPV positive and negative samples. The $\mathrm{x}$-axis indicates the melting temperatures while the y-axis indicates the fluorescence intensity. : $(\theta)$ HPV positive samples, Tm73.95 C ; \#) HPV negative samples
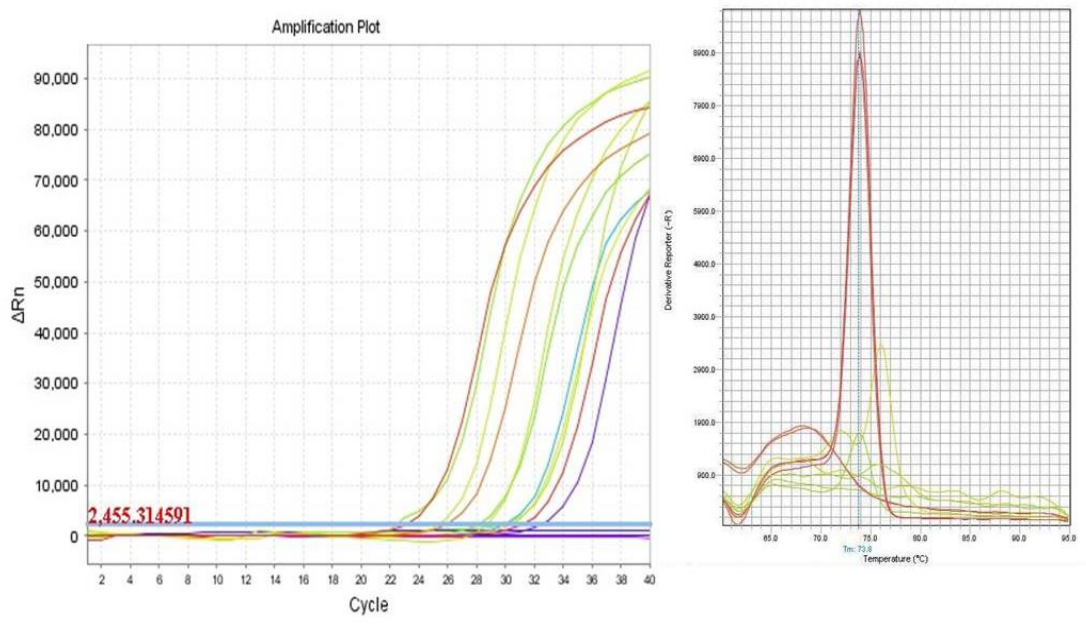
Fig.5 Genotype-specific identification of HPV DNA by multiplex PCR. Lane M, 100 pb molecular marker. TM: positive control mixture ; Lanes 2, 3, 4 and 6-10: HPV positive placental samples.; Lanes 12, 13,16 ,17, 20-23: HPV positive urine samples; Lanes14,15 and 18: untyped HPV positive urine samples; Lanes 1, 5, 11 and 19: negative HPV samples. ; NC: negative control. Different genotypes detected in each sample were shown under the figure

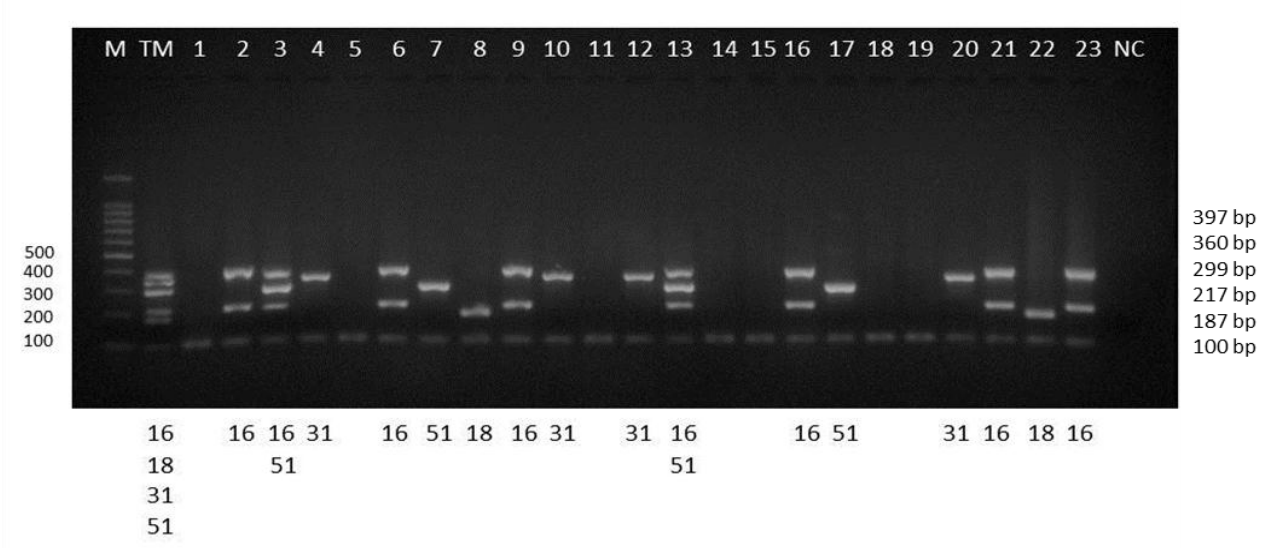

In the present study, The HPV-DNA analysis by PCR GP5+/6+was observed in $(16.6 \%)$ of placenta samples and $(6.6 \%)$ in urine samples, whereas nPCR technique found HPV positivity in $(26.7 \%)$ in placenta samples and $(36.7 \%)$ in urine samples (Fig. 1 and 2). The results indicated that, the use of primers pair MY09/11 and GP5+/6+ in a nPCR assay increases the sensitivity of HPV detection compared with PCR assay and this may be associated with the HPV genome copy number was too low to be detected after a single round PCR and this was agreement with Coser et al. (2011). The results of 128 clinical samples submitted to simple PCR and nested-PCR for detection of HPV, $67.5 \%$ were increased in detection rate compared with single PCR. On the other hand, Ludmila et al. (2013) studied infection of HPV in 251 cervical samples by PCR and nPCR methods. The HPV-DNA analysis was observed in 17 samples and in more 75 samples, respectively, increasing up to 4 times the detection of viral DNA. According to Demathe et al. (2010), the variations of HPV-DNA detection suggest a potential difference in the ability to amplify fragments of different sizes and specific HPV types, in accordance with the methods of DNA detection used, and also the types of material (smears, frozen material, paraffin or formalin embedded) and the design of primers used.

In our present study, the HPV-DNA analysis by SYBR Green qualitative real-time (Q- T) PCR was observed in $(26.7 \%)$ of placenta sample and $(36.7 \%)$ in urine sample, and from this data, there was $100 \%$ perfect agreement between placenta and urine samples tested by nested PCR and SYBR Green Q-RT PCR. we concluded that SYBR Green Q-RT PCR is a sensitive and easy-toperform technique for HPV screening and this was in agreement with De Araujo et al. (2009).

Type-specific viral identification revealed that HPV-16 had the greatest prevalence in both samples $(n=3,10 \%)$, followed by type $31(\mathrm{n}=2,6.6 \%)$; types 51 and $18(\mathrm{n}=1$, $3.3 \%)$ in both placenta and urine samples 
(Fig. 5), there was 3 urine samples not typed and that may be another HR-HPV or low HPV. Our data was in agreement with Shaltout et al. (2014) who studied four hundred and forty-three from cervical samples women; HPV DNA was detected in $10.4 \%$ of women; a single HPV-type infection was found in $6.5 \%$ and multiple infections in $3.8 \%$. The most prevalent HR types among HPV-positive women were HPV-16 (19.6\%) and HPV-31 and HPV-51 (15.2\% each).The prevalence of HPV-18 was low (6.5\%). Some investigators reported an active viral genome expression (both early and late genes) in trophoblastic cells previously when cultured with HPV $16,18,11,31$, it were shown to undergo complete life cycles in a trophoblastic cells and they decreases trophoblast cell number and cell adhesion which could result in abnormal placentation and maybe in early pregnancy loss (Liu et al., 2001 and You et al., 2003) .These effects were also confirmed by Gomez et al. (2008) who found a 3- to 6- fold greater rate of apoptosis in trophoblastic cells transfected with a plasmid containing the entire HPV-16 genome and a progressive decrease of trophoblast invasion ability from day 3 until 15 after transfection. The reasons which could explain the reduction of invasiveness of trophoblastic cells were suggested by Boulenouar et al. (2010) who found a downregulation of E- in trophoblastic cells expressing HPV -16 viral genome.

In conclusion, women with recurrent miscarriage have a higher prevalence of HPV+DNA tests than controls. The nested and real time-PCR assays are more sensitive than conventional PCR assay for detection of HPV in placental and urine samples.

\section{References}

Allison, J.L. and Schust, D.J. 2009. Recurrent first trimester pregnancy loss: revised definitions and novel causes. Curr Opin Endocrinol Diabetes Obes;16:446-50.

Antje, M.; Rochholz, H.H. and Kaatsch, H.J. 1999. Improved DNA typing of human urine by adding EDTA. Int J. Legal Med,112: 209-210.

Asato, T.; Maehama, T.; Nagai, Y.; Kanazawa, K.; Uezato, H. and Kariya, K. 2004. A large case-control study of cervical cancer risk associated withhuman papillomavirus infection in Japan, by nucleotide sequencingbasedgenotyping. J. Infect. Dis. 189:1829-1832.

Baker, T. 2009. Methods and reagents for preservation of DNA in body fluids. United States Patent application publication. 1- 24.

Bernard, H.U.; Chan, S.Y.; Manos, M.M.; Ong, C.K.; Villa, L.L.; Delius, H.; Peyton, C.L.; Bauer, H.M. and Wheeler, C.M. 1994. Identification and assessment of known and novel human papillomaviruses by polymerase chain reaction amplification, restriction fragment length polymorphisms, nucleotide sequence, and phylogenetic algorithms. J. Infect. Dis. 170:1077-1085

Boulenouar, S.; Weyn, C.; Van Noppen, M.; Moussa, A. M.; Favre, M.; Delvenne, P.O.; Bex, F.; Noël, A.; Englert, Y. and Fontaine, V. 2010. Effects of HPV-16 E5, E6 and E7 proteins on survival, adhesion, migration and invasion of trophoblastic cells. Carcinogenesis. 31:473-480.

Choi, Y.D.; Jungc, W.W.; Nama, J.H.; Choi, H.S. and Park, C.S. 2005. Detection of HPV genotypes in cervical lesions by the HPV DNA Chip and sequencing. Gynecol Oncol. 98 :369-375.

Clark, D.A.; Banwatt, D. and Croy, B.A. 1993. Murine trophoblast failure and spontaneous abortion. Am. J. Reprod. 
Immun. 29, 199- 205.

Coser, J.; Boeira, T. R.; Fonseca, A.S.; Ikuta, N. and Lunge, V.R. 2011. Human papillomavirus detection and typing using a nested-PCR-RFLP assay. Braz J infect Dis. 15(5):467-72.

De Araujo, M.R.; De Marco, L.; Santos, C.F.; Rubira-Bullen, I.R.; Ronco, G.; Pennini, I.; Vizzini, L. ; Merletti, F. and Gillio-Tos, A. 2009. GP5+/6+ SYBR Green methodology for simultaneous screening and quantification of human papillomavirus. Journal of Clinical Virology. 45: 90-95.

De Roda Husman, A.M.; Walboomers ,J.M.; Van den Brule, A.J.; Meijer, C.J. and Snijders, P.J. 1995. The use of general primers GP5 and GP6 elongated at their 3 ' ends with adjacent highly conserved sequences improves human papillomavirus detection by PCR. Journal of General Virology.76; 10571062.

Demathe, A.; Bernabé, D.G.; Garcia, J.F.; Nunes, C.M. and Miyahar G.I. 2010. Métodos de detecção de DNA de papillomavirus humano em carcinoma epidermoide de lábio. J Bras Patol Med Lab.46(2):85-90.

Donckers, J.; Scholten, R.R. and Oyen, W.J. 2012. Unexplained first trimester recurrent pregnancy loss and low venous reserves. Hum Reprod;27:2613-8.

Doorbar, J.; Quint, W.; Banks, L.; Bravo, I. G. ; Stoler, M.; Broker, T. R. and Stanley, M.A. 2012. The biology and life-cycle of human papillomaviruses. Vaccine; 30 (5): 55-70.

Einstein, M.H.; Schiller, J.T.; Viscidi, R.P.; Strickler, H.D.; Coursaget, P. and Tan, T. 2009. Clinician's guide to human papillomavirus immunology: knowns and unknowns. Lancet Infect Dis; 9:347-56.
Gomez, L.M.; Ma, Y.; Ho, C.; McGrath, C.M.; Nelson, D.B. and Parry, S. 2008. Placental infection with human papillomavirus is associated with spontaneous preterm delivery. Hum Reprod. 23:709-715.

Goon, P.; Sonnex, C.; Jani, P.; Stanley, M. and Sudhoff, H. 2008. Recurrent respiratory papillomatosis: an overview of current thinking and treatment. European Archives of Oto-RhinoLaryngology. Official Journal of the European Federation of OtoRhinoLaryngological Societies; 265(2): 147-151.

Gravitt, P.E.; Peyton, C.L.; Alessi, T.Q.; Cwheeler, C.M.; Coutle, F.; Hildesheim, E.A.; Schiffman, M.H.; Scott, D.R. and Apple, R.J. 2000. Improved Amplification of Genital Human Papillomaviruses J. Clinc. Microbiol. 38:(1)357-361.

Gravitt, P.E.; Peyton, C.L.; Apple, R.J. and Wheeler, C.M. 1998. Genotyping of 27 human papillomavirus types by using L1 consensus PCR products by a singlehybridization, reverse line blot detection method. J. Clin. Microbiol. 36:30203027.

Han, J.; Swan, D.C.; Smith, S.J.; Lum, S.H.; Sefers, S.E.; Unger, E.R. and

Tang, Y.W. 2006. Simultaneous amplification and identification of 25 human papillomavirus types with Templex technology J. Clin. Microbiol. 44:4157-4162.

Hermonat, P.L.; Han, L.; Wendel, P.; Quirk, J.G.; Stern, S.; Lowery, C. and Rechtin, T.L. 1997. Human papillomavirus DNA is more prevalent in first trimester spontaneously aborted products of conception compared to elective specimens. Virus Genes 14, 1317.

Hermonat, P.L.; Kechelava, S.; Lowery, C.L. and Korourian, S. 1998. 
Trophoblasts are the preferential target for human papillomavirus infection in spontaneously aborted products of conception. Hum. Pathol. 29, 170-174.

Ibrahim, M.; Rafaat,T.; Abbas,A.; Masoud, H. and Salama, A. $\square \square \square \square \square \square$ A novel association between cytotoxinassociated gene A (CagA) positive strain of Helicobacter pylori and unexplained recurrent early pregnancy

loss. The European Journal of Contraception and Reproductive Health Care. 19(2):78-85.

Jiang, H.L.; Zhu, H.H.; Zhou, L.F.; Chen, F. and Chen, Z. 2006. Genotyping of human papillomavirus in cervical lesions by $\mathrm{L} 1$ consensus, PCR, and the Luminex xMAP system. J. Med. Microbiol. 55:715-720.

Khan, G.; Kangro, H.o.; Coates, P.j. and Heath, R.B. 1991. Inhibitory effects of urine on the polymerase chain reaction for cytomegalovirus DNA. J Clin Pathol.44(5): 360-365.

Kleter, B.; van Doorn, L.J.; Schrauwen, L.; Molijn, A.; Sastrowijoto, S.; Schegget, J.T.; Lindeman, J.; ter Harmsel, B.; Burger, M. and Quint, W. 1999. Development and clinical evaluation of a highly sensitive PCR-reverse hybridization line probe assay for detection and identification of anogenital human papillomavirus. J. Clin. Microbiol. 37:2508-2517.

Liu, Y.; You, H.; Chiriva-Internati, M.; Korourian, S.; Lowery, C.L.; Carey, M.J.; Smith, C.V. and Hermonat, P.L. 2001. Display of complete life cycle of human papillomavirus type 16 in cultured placental trophoblasts. Virology. 290:99-105.

Ludmila, E.; Nunes, E.; Collares, T.; da Silveira, M.F. and Seixas, F. 2013. Comparison between two methods for moleCular CharaCterization of human papillomavirus, J bras Doenças Sex
Transm. 25 (1):13-15.

Malhomme, O.; Dutheil, N.; Rabreau, M.; Armbruster-Moraes, E.; Schlehofer, J.R. and Dupressoir, T. 1997. Human genital tissues containing DNA of adenoassociated virus lack DNA sequences of the helper viruses adenovirus, herpes simplex virus or cytomegalovirus but frequently contain human papillomavirus DNA. J. Gen. Virol. 78, 1957-1962.

Melbye, M. and Frisch, M. 1998. The role of human papillomaviruses in anogenital cancers. Semin. Cancer Biol. 8: 307-313.

Morie, N.; Yamamoto, T.; Tone, S.; Murai, T.; Ohkawara, T.; Matsunami, T.; Koizumi, M.; Takagi, Y.; Yamaguchi, J.; Kondo, N.;Nishihira, J.; Horikawa, T. and Yoshiki, T. 2008. Genotyping of Human Papillomaviruses by a Novel One-Step Typing Method with Multiplex PCR and Clinical Applications. Journal of clinical microbiology, Vol. 46 (4) 11611168.

Noventa, M.; Andrisani, A.; Gizzo, S.; Nardelli, G. B. and Ambrosini, G. 2014. Is it time to shift the attention on early stages embryo development to avoid inconclusive evidence on HPV-related infertility. Reproductive Biology and Endocrinology. 12:48.

Sasagawa, T.; Minemoto, Y.; Basha, W.; Yamazaki, H.; Nakamura, M.; Yoshimoto, H.; Sakaike, J. and Inoue, M. 2000. A new PCR-based assay amplifies the E6-E7 genes of most mucosal human papillomaviruses (HPV). Virus Res. 67:127-139.

Shaltout, M.F.; Sallam, H.N.; AbouSeeda, M. ; Moiety, F.; Hemeda, H.; Ibrahim, A.; Sherbini, M.E.; Rady, H.; Gopala, K. and De Antonio, R. 2014. Prevalence and type distribution of human papillomavirus among women older 
than 18 years in Egypt: a multicenter, observationalstudy. International Journal of Infectious Diseases. (29); 226-231.

SPSS 2007. Statistical Package for Social Sciences, SPSS Inc, Chicago, IL, USA Copyright $\odot$ for Windows, version 160 SPSS.

Strauss, S.; Jordens, J.Z.; McBride, D.; Sonnex, C.; Edwards, S.; Desselberger, U.; Watt, P. and Gray, J.J. 1999. Detection and typing of human papillomavirus DNA in paired urine and cervical scrape. EuropeanJournal of Epidemiology. 15: 537-543.

Trofatter, K.F. 1997. Diagnosis of human papillomavirus genital tract infection. Am J Med.; 102 (5A):2127.

Walsh, S.P., Metzger, D. A., and Russell, H. 1991. Chelex 100 as a medium for simple extraction of DNA for PCRbased typing from forensic material. Biotechniques. 10, 506-513.
Weimin, Q.U.; Gang, J.; Yvette,V.; CHEE, J.C.; Gloria, L.Y.F.; Robert, O.S.K. and Robert, D.B 1997. PCR Detection of Human pillomavirus: Comparison between MY09/MY11 and GP51/GP61 Primer Systems. J.Clin. Microbiol. 35: 1304-1310.

Yoshikawa, H.; Kawana, T.; Kitagawa, K.; Mizuno, M.; Yoshikura, H. and Iwamoto, A. 1991. Detection and typing of multiple genital human papillomaviruses by DNA amplification with consensus primer. Jpn. J. Cancer Res. 82:524-531.

You, H.; Liu, Y.; Agrawal, N.; Prasad, C.K.; Chiriva-Internati, M.; Lowery, C.L.; Kay, H.H. and Hermonat, P.L. 2003. Infection, replication, and cytopathology of human papillomavirus type 31 in trophoblasts. Virology. (316):281 -289.

\section{How to cite this article:}

Aya A. Hammad, Neveen A. Ashaat, Samah F. Darwish, I.I. Moustafa and Amin, A.S. 2016. Detection and Genotyping of Human Papilloma Virus (HPV) As a Cause of Recurrent Early Pregnancy Loss. Int.J.Curr.Microbiol.App.Sci. 5(1): 686-698 http://dx.doi.org/10.20546/ijcmas.2016.501.069 